\title{
One-pot synthesis of oxazolidinones and five-membered cyclic carbonates from epoxides and chlorosulfonyl isocyanate: theoretical evidence for an asynchronous concerted pathway
}

\author{
Esra Demir ${ }^{1}$, Ozlem Sari ${ }^{2}$, Yasin Çetinkaya ${ }^{3}$, Ufuk Atmaca ${ }^{1,3}$, Safiye Sağ Erdem ${ }^{4}$ \\ and Murat Çelik ${ }^{*}$
}

\section{Full Research Paper}

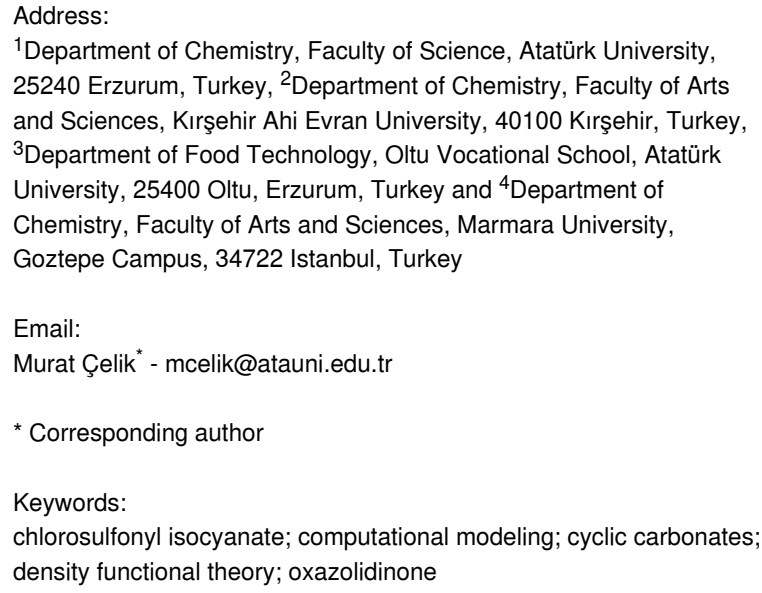

${ }^{1}$ Department of Chemistry, Faculty of Science, Atatürk University, 25240 Erzurum, Turkey, ${ }^{2}$ Department of Chemistry, Faculty of Arts and Sciences, Kırşehir Ahi Evran University, 40100 Kırşehir, Turkey, ${ }^{3}$ Department of Food Technology, Oltu Vocational School, Atatürk University, 25400 Oltu, Erzurum, Turkey and ${ }^{4}$ Department of Chemistry, Faculty of Arts and Sciences, Marmara University, Goztepe Campus, 34722 Istanbul, Turkey

Email:

Murat Çelik - mcelik@atauni.edu.tr

* Corresponding author

Keywords:

chlorosulfonyl isocyanate; computational modeling; cyclic carbonates; density functional theory; oxazolidinone

\author{
Beilstein J. Org. Chem. 2020, 16, 1805-1819. \\ doi:10.3762/bjoc. 16.148 \\ Received: 09 April 2020 \\ Accepted: 02 July 2020 \\ Published: 21 July 2020 \\ Associate Editor: P. Schreiner \\ (C) 2020 Demir et al.; licensee Beilstein-Institut. \\ License and terms: see end of document.
}

\footnotetext{
Abstract

The one-pot reaction of chlorosulfonyl isocyanate (CSI) with epoxides having phenyl, benzyl and fused cyclic alkyl groups in different solvents under mild reaction conditions without additives and catalysts was studied. Oxazolidinones and five-membered cyclic carbonates were obtained in ratios close to $1: 1$ in the cyclization reactions. The best yields of these compounds were obtained in dichloromethane (DCM). Together with 16 known compounds, two novel oxazolidinone derivatives and two novel cyclic carbonates were synthesized with an efficient and straightforward method. Compared to the existing methods, the synthetic approach presented here provides the following distinct advantageous: being a one-pot reaction with metal-free reagent, having shorter reaction times, good yields and a very simple purification method. Moreover, using the density functional theory (DFT) method at the M06-2X/6-31+G(d,p) level of theory the mechanism of the cycloaddition reactions has been elucidated. The further investigation of the potential energy surfaces associated with two possible channels leading to oxazolidinones and five-membered cyclic carbonates disclosed that the cycloaddition reaction proceeds via an asynchronous concerted mechanism in gas phase and in DCM.
} 


\section{Introduction}

Oxazolidinones (1), five-membered heterocyclic rings containing an ester group adjacent to a nitrogen atom, are important compounds in synthetic and pharmaceutical chemistry because of their considerable use as antibiotics [1], immunomodulators [2], antibacterials [3], as well as synthetic intermediates and chiral auxiliaries for various organic conversions [4-7]. Linezolid [1-3] (3) and cytoxazone [8,9] (4) are oxazolidinone derivatives having significant biological activities. Linezolid (3) is the first oxazolidinone drug approved in 2000 by the Food and Drug Administration (FDA) for the treatment of multidrug resistant Gram-positive bacterial infections (Scheme 1) [10] Cytoxazone is a microbial metabolite exhibiting potent cytokine-modulating activity. Tedizolid phosphate (trade name Sivextro), which exhibits antibiotic activity is another oxazolidinone drug approved by the FDA in 2014 [11]. Befloxatone and toloxatone, $N$-substituted phenyloxazolidinone derivatives, are reversible inhibitors of monoamine oxidase (MAO) [12,13] $\mathrm{N}$-Aryloxazolidinedione compounds, which are toloxatone derivatives, have been reported to exhibit good affinity for human MAO-A [14].

Five-membered cyclic carbonate (1,3-dioxolan-2-one) (2) and its derivatives are valuable synthetic targets on account of several applications and pertinent properties. They are found in various natural and potential pharmaceutical products [15]. Moreover, they are used as electrolyte components in Li-ion rechargeable cells and as aprotic polar solvent with high boiling point as alternative of dangerous solvents because of their good biodegradability and low toxicity [16-18]. Synthetic intermediates for ring-opening polymerization of the compounds containing cyclic carbonates such as methyl 4,6- $O$-benzylidene-2,3-O- carbonyl- $\alpha$-D-glucopyranoside (MBCG) (5) $[19,20]$ and glycerol carbonate (6) [21] were also reported (Scheme 1).

Therefore, numerous synthetic approaches have been developed to date for the preparation of oxazolidinones and fivemembered cyclic carbonates of various structures. The most well-known strategies for the synthesis of oxazolidinones are the reaction of an amino alcohol with phosgene [5,22], the carbonylation reaction of $\beta$-amino alcohols with $\mathrm{CO}_{2}$ or dialkyl carbonates [23-27], the multicomponent reaction of rare-earth metal amides [28], the reaction of $\mathrm{CO}_{2}$ with propargylamines or aziridines $[29,30]$ and the cycloaddition reaction of epoxides with isocyanates $[31,32]$. On the other hand, for the synthesis of five-membered cyclic carbonates, the cycloaddition of $\mathrm{CO}_{2}$ to epoxides, the reaction with the metal complexes or catalysts, and the reaction of a diol with toxic phosgene are the most common processes [16,17,33-36].

CSI, a highly reactive and versatile isocyanate, reacts with epoxides to give five-membered cyclic carbonates and oxazolidinones [37-39]. In 1984, Keshava Murthy and Dhar reported the synthesis of five-membered cyclic carbonates and oxazolidinones from various epoxides in two steps using CSI and $\mathrm{KOH}$ in benzene/dichloromethane [40,41]. In 1986, De Meijere and co-workers reported the cycloaddition of CSI to epoxides at $-78{ }^{\circ} \mathrm{C}$ to give five-membered cyclic carbonates and oxazolidinones [42]. They reported seven examples; three of these attempts resulted in five-membered cyclic carbonates as the sole product while two cases produced oxazolidinones, and the other two reactions gave mixtures of two products. These reports prompted us to explore this reaction in more detail. In our<smiles>COc1ccc([C@H]2NC(=O)O[C@@H]2CO)cc1</smiles><smiles>COC1OC2CO[C@@H](c3ccccc3)O[C@H]2C2OC(=O)OC12</smiles>

5, MBCG

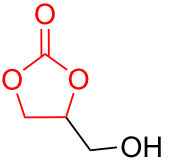

6, glycerol carbonate 
previous studies, we investigated the reactions of CSI with various substrates such as carboxylic acids, alkenes and allyl or benzyl alcohols [43-46]. As a continuation of these studies, we performed one-pot syntheses of the title compounds by optimizing the reaction of CSI with epoxides in different solvents under mild conditions and compared the reaction mechanism with previously proposed mechanisms using theoretical calculations.

Keshava Murthy and Dhar [41] postulated a mechanism involving a zwitterionic intermediate. $\mathrm{C}-\mathrm{O}$ bond cleavage in this unstable and strained intermediate gives rise to a short-lived carbonium ion which will be attacked by the nucleophilic part of the zwitterion in a concerted way (Scheme 2a). De Meijere and co-workers [42] proposed a mechanism involving a 1,5dipolar intermediate (Scheme $2 b$ ).

To the best of our knowledge, there is no computational mechanistic study in the literature regarding the reaction of epoxides with CSI. On the other hand, the reactions of isocyanates with monofluoroalkenes and nitrones were modeled with the Møller-Plesset (MP2) perturbation theory and M06-2X functional, respectively $[37,47]$. According to these computational studies, such reactions of isocyanates may proceed through a concerted pathway. The remaining uncertainties in the mechanisms of the similar reactions inspired us to carry out quantum chemical calculations for the formation of oxazolidinone and five-membered cyclic carbonates.

\section{Results and Discussion}

First, we synthesized various epoxides $(\mathbf{7 a}-\mathbf{j})$ in the presence of $m e t a$-chloroperbenzoic acid ( $m$-CPBA), from the corresponding alkenes dissolved in DCM at room temperature. The general experimental conditions for conversion of alkenes to related epoxides were given in Supporting Information File 1. For the synthesis of oxazolidinones and five-membered cyclic carbonates, the most effective solvent was determined based on the reaction of 8-oxabicyclo[5.1.0]octane (7b) with CSI (Table 1) which was the first reaction performed in this study. The reaction was carried out in acetone, THF, acetonitrile, dichloromethane, toluene, and $n$-hexane/dichloromethane. While no reaction was observed in diethyl ether, the best conversion was achieved in dichloromethane. Benzene was not used as a solvent because of having toxic and carcinogenic effects.

Herein, we report mild reaction conditions for the one-pot synthesis of oxazolidinones and five-membered cyclic carbonates from various epoxides $(\mathbf{7} \mathbf{a}-\mathbf{j})$ at room temperature without using any catalyst.

After having identified the optimal conditions, various epoxides were treated with chlorosulfonyl isocyanate at room temperature to give mixtures of cyclic carbonates and oxazolidinones in ratios close to 1:1 as shown in Table 2. trans-Stilbene (7d) and cis-stilbene epoxids (7e) in the presence of CSI gave trans-4,5-diphenyl-1,3-dioxolan-2-one (8d), trans-4,5-diphenyl-

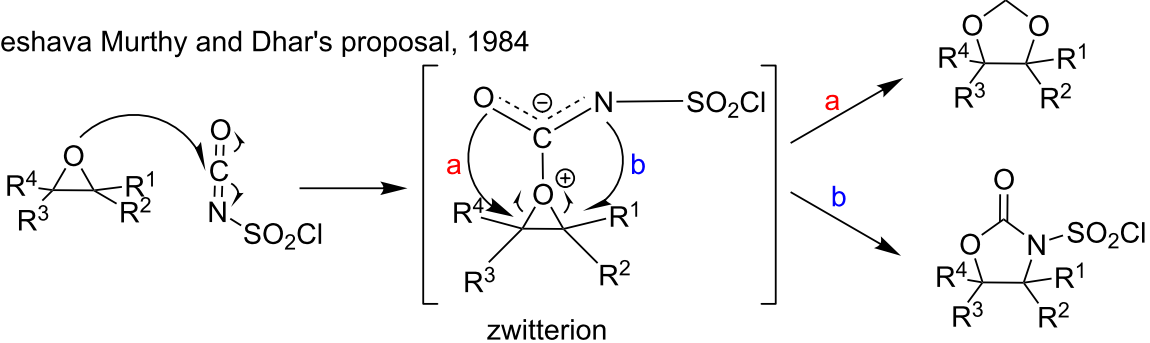

b) De Meijere and co-workers's proposal, 1986

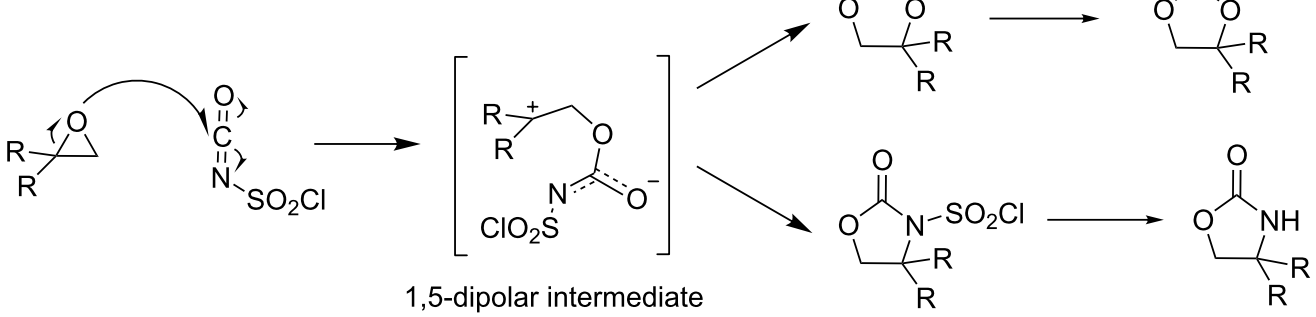


Table 1: Solvent optimization for the synthesis of five-membered cyclic carbonate $\mathbf{8 b}$ and oxazolidinone $\mathbf{9 b}$ from epoxide $\mathbf{7 b}$

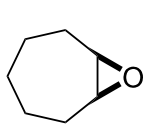

$7 \mathbf{b}$

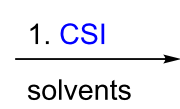

2. $\mathrm{H}_{2} \mathrm{O}$

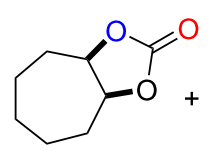

$8 b$

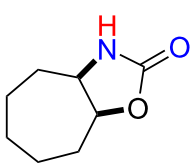

$9 b$

\begin{tabular}{llll}
\hline Entry & Solvents & \multicolumn{2}{c}{ Products $(\%)^{\mathrm{a}}$} \\
\cline { 3 - 4 } & & $\begin{array}{l}\text { Five-membered cyclic } \\
\text { carbonate } 8 \mathbf{b}\end{array}$ & Oxazolidinone $\mathbf{9 b}$ \\
\hline 1 & acetone & 11 & 15 \\
2 & $\mathrm{THF}$ & 15 & 12 \\
3 & diethyl ether & no reaction & 34 \\
4 & $\mathrm{CH}_{3} \mathrm{CN}$ & 39 & $\mathbf{4 5}$ \\
$\mathbf{5}$ & dichloromethane & $\mathbf{4 8}$ & 15 \\
6 & toluene & 13 & 19 \\
7 & n-hexane/dichloromethane $(1: 1)$ & 21 & \\
\hline
\end{tabular}

alsolated yield.

Table 2: Direct conversion of epoxides $7 \mathbf{a}-\mathbf{j}$ with CSI into five-membered cyclic carbonates $\mathbf{8} \mathbf{a}-\mathbf{j}$ and oxazolidinones $9 \mathbf{a}-\mathbf{j}$.

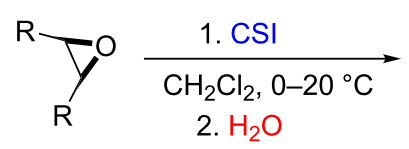

$7 a-j$<smiles>[R]C1OC(=O)OC1[R]</smiles>

$\mathbf{8} \mathbf{a}-\mathbf{j} \quad$ ca. $1: 1 \quad \mathbf{9} \mathbf{a}-\mathbf{j}$

\begin{tabular}{|c|c|c|c|}
\hline \multirow[t]{2}{*}{ Entry } & \multirow[t]{2}{*}{ Substrates $^{a}$} & \multicolumn{2}{|c|}{ Products $^{b}(\%)$} \\
\hline & & $\begin{array}{c}\text { Five-membered cyclic } \\
\text { carbonates }^{c}\end{array}$ & Oxazolidinones $^{\mathrm{C}}$ \\
\hline 1 & $7 a$ & $\begin{array}{c}42 \% \\
8 a \text { [48] }\end{array}$ & $\begin{array}{c}38 \% \\
9 a[49]\end{array}$ \\
\hline 2 & $7 b$ & $8 b$ [50] & $\begin{array}{c}45 \% \\
9 b[51]\end{array}$ \\
\hline 3 & 7c & $\begin{array}{c}51 \% \\
8 c[50]\end{array}$ & $\begin{array}{c}40 \% \\
9 c\end{array}$ \\
\hline
\end{tabular}


Table 2: Direct conversion of epoxides $7 \mathbf{a}-\mathbf{j}$ with CSI into five-membered cyclic carbonates $\mathbf{8 a}-\mathbf{j}$ and oxazolidinones $9 \mathbf{a}-\mathbf{j}$. (continued)

4<smiles>c1ccc(C2OC2c2ccccc2)cc1</smiles>

7d<smiles>c1ccc(C2OC2c2ccccc2)cc1</smiles>

$7 e$<smiles>c1ccc(C2CO2)cc1</smiles><smiles>c1ccc(CC2CO2)cc1</smiles>

$7 \mathrm{~g}$

8<smiles>c1ccc2c(c1)CC1OC21</smiles>

$7 \mathrm{~h}$

9<smiles>[Te]C12CC(c3ccccc31)C1OC12</smiles>

10

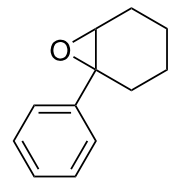

$7 \mathbf{j}$<smiles>O=C1O[C@@H](c2ccccc2)[C@@H](c2ccccc2)O1</smiles>

$43 \%$

8d [50]<smiles>O=C1OC(c2ccccc2)[C@H](c2ccccc2)O1</smiles>

$44 \%$

8e [50]<smiles>O=C1OCC(c2ccccc2)O1</smiles>

$49 \%$

$8 f$ [16]<smiles>O=C1OCC(Cc2ccccc2)O1</smiles>

$41 \%$

8g [16]<smiles>O=C1OC2Cc3ccccc3C2O1</smiles>

$45 \%$

8h [54]<smiles>[14CH3]C1c2ccccc2C2C[C@@H]1C1OC(=O)OC21</smiles>

$8 \mathbf{i}$

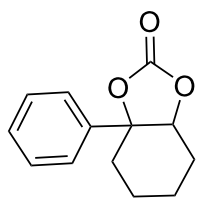

$44 \%$<smiles>O=C1N[C@H](c2ccccc2)C(c2ccccc2)O1</smiles>

$34 \%$

9d [52]<smiles>O=C1NC(c2ccccc2)C(c2ccccc2)O1</smiles>

$41 \%$

9e [52]<smiles>O=C1NC(c2ccccc2)CO1</smiles>

$42 \%$

9f [16]<smiles>O=C1NC(Cc2ccccc2)CO1</smiles>

$35 \%$

9g [53]<smiles>O=C1NC2c3ccccc3CC2O1</smiles>

9h [52]<smiles>O=C1NC2C3CC(c4ccccc43)C2O1</smiles>

$9 i$

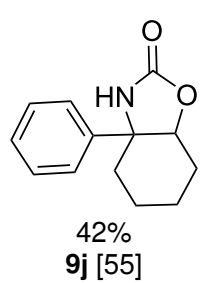

asynthesis of epoxides 7a-j: alkenes (1 equiv), $m$-CPBA (1.2 equiv), in DCM; bisolated yield; cliterature.

oxazolidin-2-one (9d) and cis-4,5-diphenyl-1,3-dioxolan-2-one (8e), cis-4,5-diphenyloxazolidin-2-one (9e), respectively (Table 2). These results show that the relative configuration is preserved. 4-Phenyl-1,3-dioxolan-2-one (8f) and 4-phenyloxazolidin-2-one (9f) were obtained from the reaction of CSI with styrene oxide (7f) showing the regioselective nature of the reac- 
tion. In addition, we report the synthesis of the novel oxazolidinone derivatives $\mathbf{8 i}$, and $\mathbf{8 j}$ and 1,3-dioxolan-2-ones $\mathbf{9 c}$ and $\mathbf{9 i}$. Furthermore, a more efficient and straightforward method for the formation of the previously known $\mathbf{8 a}-\mathbf{h}, \mathbf{9 a}-\mathbf{b}, \mathbf{9 d}-\mathbf{h}$ and $\mathbf{9 j}$ is being described.

In the study of Keshava Murthy and Dhar, five-membered cyclic carbonates and oxazolidinones from epoxides were synthesized in two stages using $\mathrm{CSI}$ and $\mathrm{KOH}$ in dry benzene/ dichloromethane $(5: 1)$ at $-10{ }^{\circ} \mathrm{C}[40,41]$. They reported fivemembered cyclic carbonates as the main products in the reaction mixture in good yields (83.9-95.9\%, totally), but with only five examples. It is also known today that benzene is carcinogenic, and not preferred as a solvent unless it is necessary. This two-step methodology required several purification methods. However, our purification process is remarkably simple and shorter. Moreover, using ten examples (Table 2), twenty distinct products were synthesized in good yields (76-93\%, totally).

On the other hand, in the study of De Meijere and co-workers, the reaction started at $-78{ }^{\circ} \mathrm{C}$ to give five-membered cyclic carbonates and oxazolidinones using seven examples [42] Three of these attempts resulted in five-membered cyclic carbonates as the sole products while in two cases oxazolidinones were produced, and the other two reactions gave mixtures of two products. The purification process of this method also required several steps resulting in relatively lower yields (20-67\% yields, totally). Compared to this study, our study provided higher yields in shorter reaction times under mild condi- tions using a simple purification method. Apparently, our protocol describes a reasonable methodology for the conversion of epoxides to protected 1,2-diols and 2-amino alcohols. Attention is drawn on these 1,2-oxygen and/or nitrogen units since they are present in natural products ranging from small molecules, such as sugars, lipids and amino acids to huge molecules [56].

\section{Computational results}

A detailed mechanistic investigation of the synthesis of oxazolidinone and five-membered cyclic carbonate derivatives by the reaction between epoxide $7 \mathbf{f}$ and CSI has been performed.

\section{Formation of oxazolidinone $9 f$}

There are two possible channels for the cyclization reaction of epoxide 7f with CSI to form oxazolidinone intermediates 10 and $\mathbf{1 1}$ as shown in Figure 1. In both transition states it is found that the ring-opening reaction of the epoxide, a nucleophilic attack of $\mathrm{N} 4$ onto $\mathrm{C} 1$ or $\mathrm{C} 2$ and an attack of $\mathrm{O} 3$ on $\mathrm{C} 5$ occur in an asynchronous concerted manner. The first transition state (TS1) corresponds to the nucleophilic attack of N4 onto the C2 of $7 \mathbf{f}$ leading to oxazolidinone intermediate 10. The alternative transition state (TS1') corresponds to the nucleophilic attack of $\mathrm{N} 4$ onto the less sterically encumbered $\mathrm{C} 1$ atom of the epoxide 7f forming intermediate 11. Optimized geometries of transition structures are depicted in Figure 1.

Our calculated results for the reaction indicate $17.4 \mathrm{kcal} / \mathrm{mol}$ (gas phase) and $26.7 \mathrm{kcal} / \mathrm{mol}$ (in DCM) preference for the TS1 over the TS1' (Figure 2). Therefore, attack by N4 of CSI on the

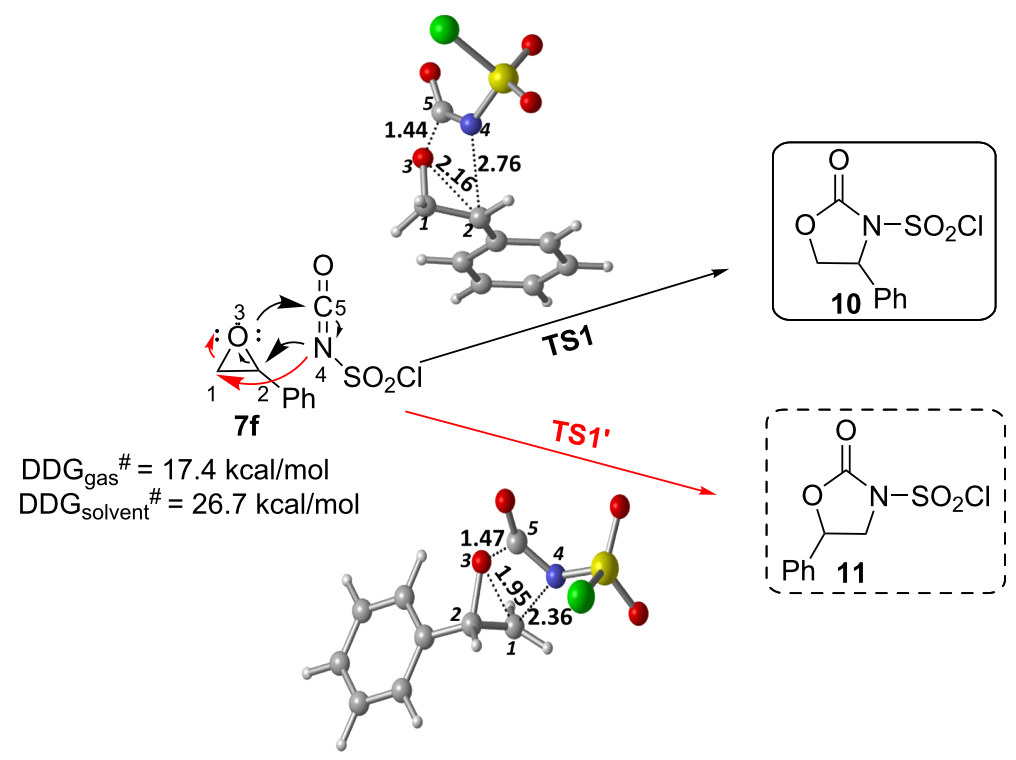

Figure 1: Possible pathways for the formation of oxazolidinone intermediates 10 and 11. Optimized transition structures at PCM/M06-2X/6$31+G(d, p) / / M 06-2 X / 6-31+G(d, p)$ level in DCM. Distances are given in $\AA$. 

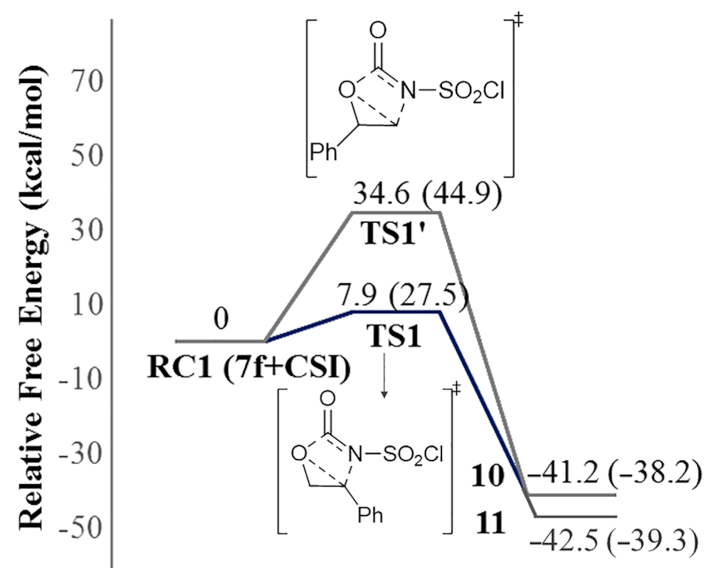

Reaction Coordinate

Figure 2: Potential energy profile related to the formation of oxazolidinone intermediates 10 and 11 at the PCM/M06-2X/6-31+G(d,p)//M06$2 X / 6-31+G(d, p)$ level in DCM. Gas phase energies are shown in parenthesis. (The polarization effect of the solvent was considered implicitly.)
$\mathrm{C} 2$ of epoxide is found to be energetically the most favored approach.

The epoxide ring opening and formation of the $\mathrm{O}-\mathrm{C}(=\mathrm{O})$ bond are almost completed before the $\mathrm{C}-\mathrm{N}$ bond is formed. The changes in bond lengths along the intrinsic reaction coordinate (IRC) are depicted in Figure $3 \mathrm{a}$ and $\mathrm{b}$ as an acceptable approach in the literature [57]. For the formation of 10, the $\mathrm{O}-\mathrm{C}(=\mathrm{O})$ distance is shortened and $\mathrm{C} 2-\mathrm{O} 3$ bond is elongated rapidly until reaching the product, while the $\mathrm{C} 2-\mathrm{N} 4$ distance is shortened from $2.76 \AA$ in TS1 to $2.59 \AA$ in I-41 (Figure 3a). Note that I-41 is not yet the product but the 41 st point in the IRC where the C2-N4 distance will eventually decrease to the bond distance when the number of IRC points are increased. These results refer to asynchronous events. The same trend is observed for the formation of $\mathbf{1 1}$ as shown in Figure 3b. Noteworthy, the $\mathrm{C} 2-\mathrm{N} 4$ bond length does not change much along the IRC for the formation of 10; however, it is shortened more rapidly to give $\mathbf{1 1}$. The presence of partial double bond be-
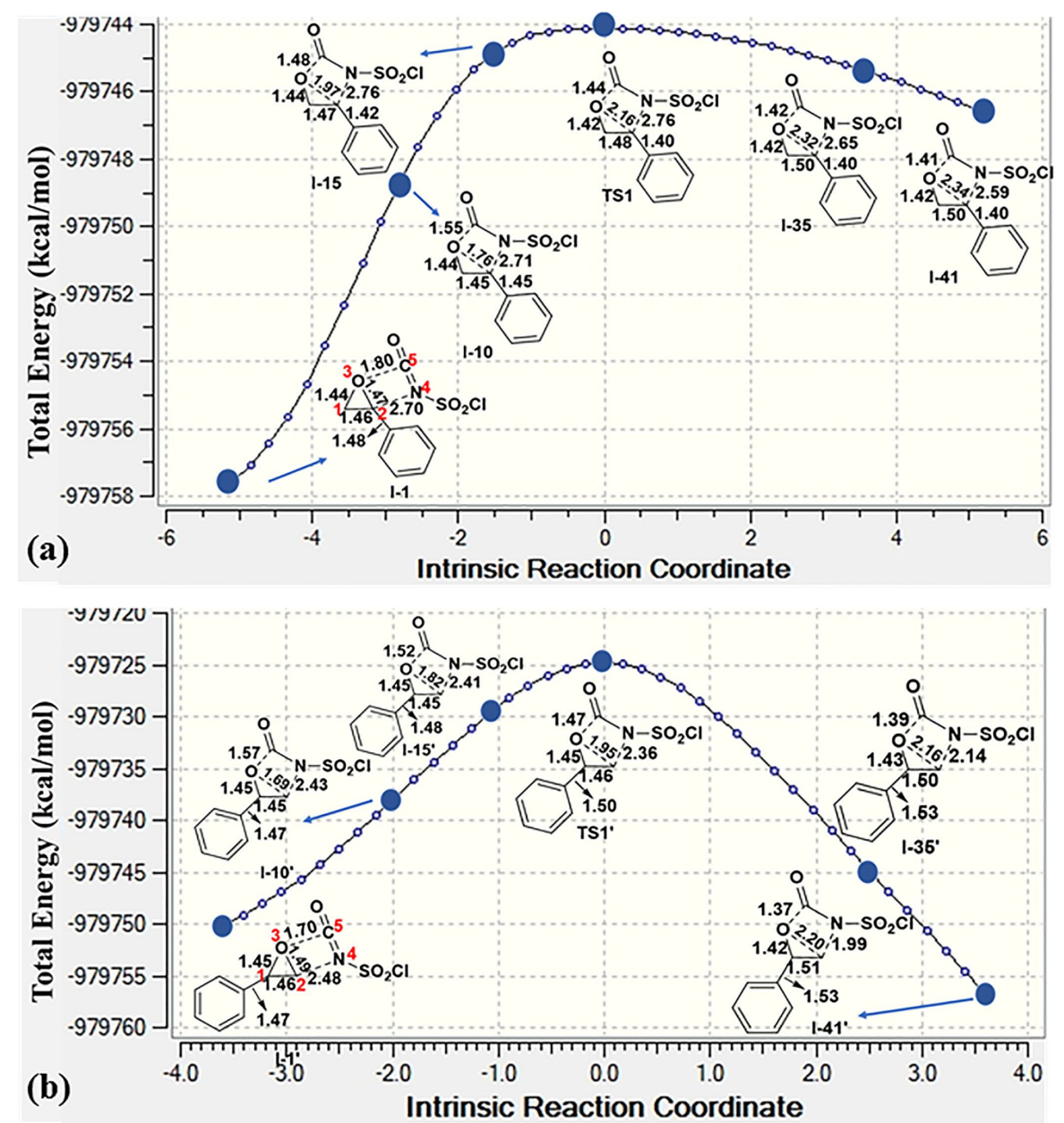

Figure 3: IRC calculated for the formation of (a) $\mathbf{1 0}$ and (b) $\mathbf{1 1}$ at M06-2X/6-31+G(d,p) level. I-1, I-15, I-35, I-41, etc. are the selected points along the coordinate. Distances are given in $\AA$. 
tween $\mathrm{C} 2-\mathrm{C}(\mathrm{Ph})$ (benzylic position) allows electron delocalization around the reacting center, which results in stabilization of the transition state and so lowering the activation energy barrier (Figure 3a). On the other hand, stabilization of the benzylic cation is not possible along the IRC path for TS1' (Figure 3b), since the bond distance $\mathrm{C} 2-\mathrm{C}(\mathrm{Ph})$ is found as around $1.50 \AA$ showing a single bond character. This can be the main reason for the predominant formation of intermediate $\mathbf{1 0}$ which results in the regioselective formation of oxazolidinone $\mathbf{9 f}$

Optimized geometries for reactant complex RC1 (7f+CSI), transition state TS1 and $\mathbf{1 0}$ for the selected path are depicted in
Figure 4. This step is common for all paths studied which will be described below.

Once $\mathbf{1 0}$ is formed, the next step is addition of water. This step can occur along three different pathways namely path 1a, path $1 \mathrm{~b}$ and path 2 as shown in Scheme 3. The potential energy profile of each path was generated relative to the energy of the initial reactant complex RC1 (7f+CSI) (Figure 5). Paths 1a and $1 \mathrm{~b}$ represent the protonation of the ring nitrogen by one and two water molecules, respectively, and the departure of 12. In path 1a, the transformation of the TS2 to $9 f$ involves the shortening of the N4-H8 distance from 1.46 to $1.01 \AA$ and S6-O7 distance

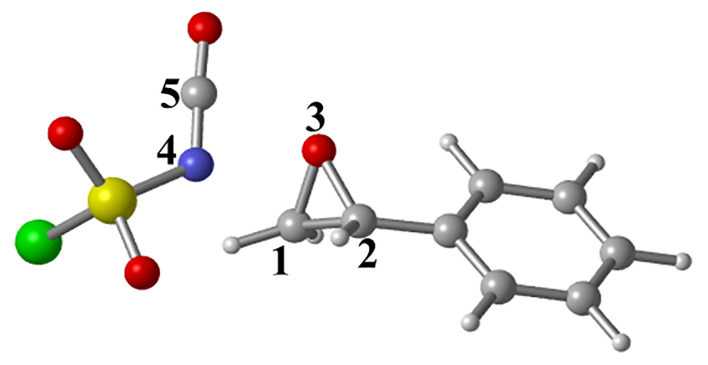

RC1 (7f + CSI)

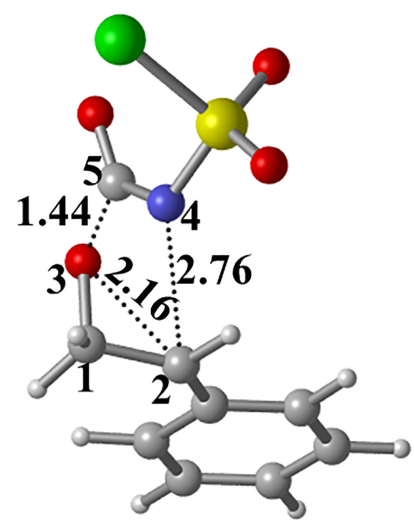

TS1

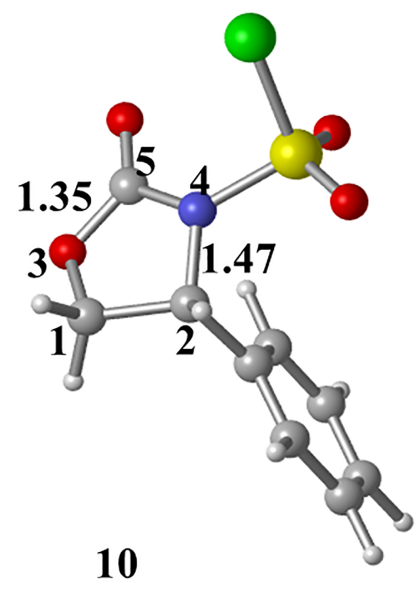

Figure 4: Optimized geometries for the stationary points for the formation of 10 at $P C M(D C M) / M 06-2 X / 6-31+G(d, p) / / M 06-2 X / 6-31+G(d, p)$ level (common step of path 1a, path $1 \mathrm{~b}$ and path 2). Distances are given in $\AA$.

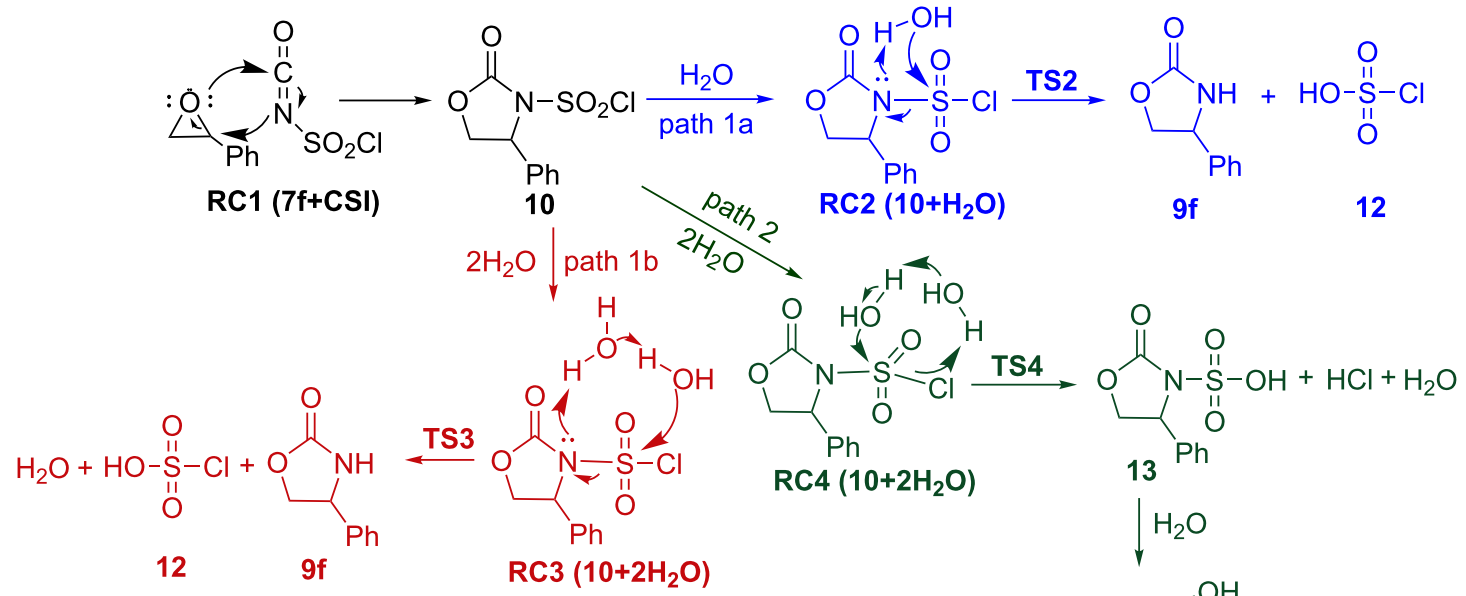
RC3 $\left(10+2 \mathrm{H}_{2} \mathrm{O}\right.$<smiles>O=C1NC(c2ccccc2)CO1</smiles><smiles>O=C1OCC(O)C1(O)S(=O)(=O)O</smiles>

RC5 $\left(13+\mathrm{H}_{2} \mathrm{O}\right)$ 


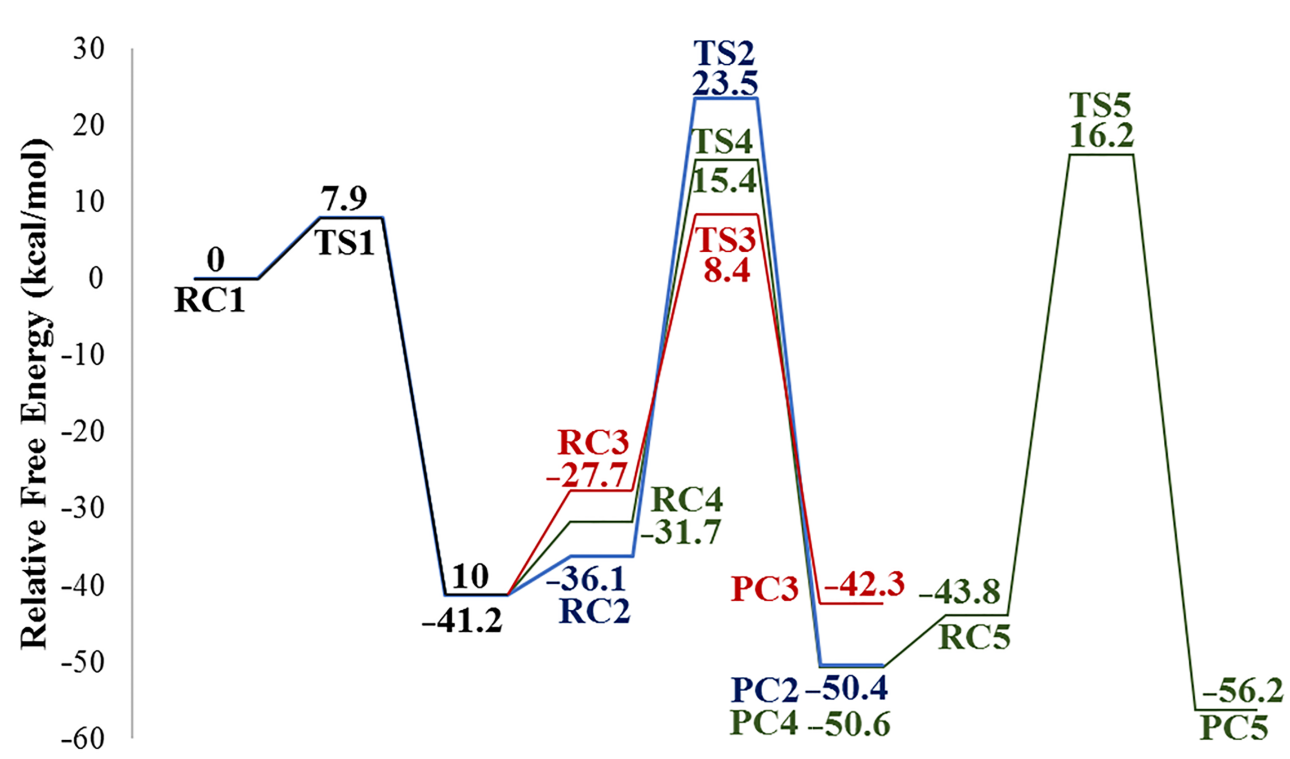

\section{Reaction Coordinate}

Figure 5: Potential energy profiles for paths $1 \mathrm{a}$ (blue), $1 \mathrm{~b}$ (red), 2 (green) and relative Gibbs free energies ( $\mathrm{kcal} / \mathrm{mol})$ in DCM related to the formation of 9 at $P C M(D C M) / M 06-2 X / 6-31+G(d, p) / / M 06-2 X / 6-31+G(d, p)$ level.

from 1.89 to $1.54 \AA$ (Supporting Information File 1, Figure S1). This path occurs via the four-membered ring transition state TS2 with an energy barrier of $23.5 \mathrm{kcal} / \mathrm{mol}$ relative to $\mathbf{R C 1}$ $(\mathbf{7 f}+\mathbf{C S I})$.

Another scenario (path $1 \mathrm{~b}$ ) is the direct participation of two water molecules in six-membered TS3 leading to the target product 9f. As can be seen from Figure 6, the distance of N4-H8 is calculated as $1.41 \AA$ in TS3, which is further shortened to $1.06 \AA$ in $\mathbf{P C 3}\left(\mathbf{9 f}+\mathbf{1 2}+\mathbf{H}_{\mathbf{2}} \mathbf{O}\right)$. Obviously, the proton shuttle activation mechanism pathway is energetically more favorable, which involves a lower barrier of $8.4 \mathrm{kcal} / \mathrm{mol}$ with respect to $\mathbf{R C 1}(\mathbf{7 f + C S I})$ (Figure 5).
Alternatively, the mechanism may involve path 2 where the addition of water molecules to the chlorosulfonyl moiety and the departure of $\mathrm{H}_{2} \mathrm{SO}_{4}$ are observed (Scheme 3). The first step of path 2 involves addition of two water molecules to $\mathbf{R C 4}$ $\left(\mathbf{1 0}+\mathbf{2} \mathrm{H}_{2} \mathrm{O}\right)$ resulting in elimination of hydrated $\mathrm{HCl}$ and formation of 13. The calculated free energy of activation was found to be $15.4 \mathrm{kcal} / \mathrm{mol}$ with respect to $\mathbf{R C 1}$ (7f+CSI) (Figure 5). The final step of path 2 takes place from RC5 $\left(\mathbf{1 3}+\mathbf{H}_{2} \mathrm{O}\right)$ passing through TS5 and forming the target product 9f. This step requires an activation free energy of $16.2 \mathrm{kcal} / \mathrm{mol}$ with respect to the initial reactant complex RC1 (7f+CSI) (Figure 5). The overall process is exothermic by $56.2 \mathrm{kcal} / \mathrm{mol}$. Three-dimensional (3D) views of all the opti-

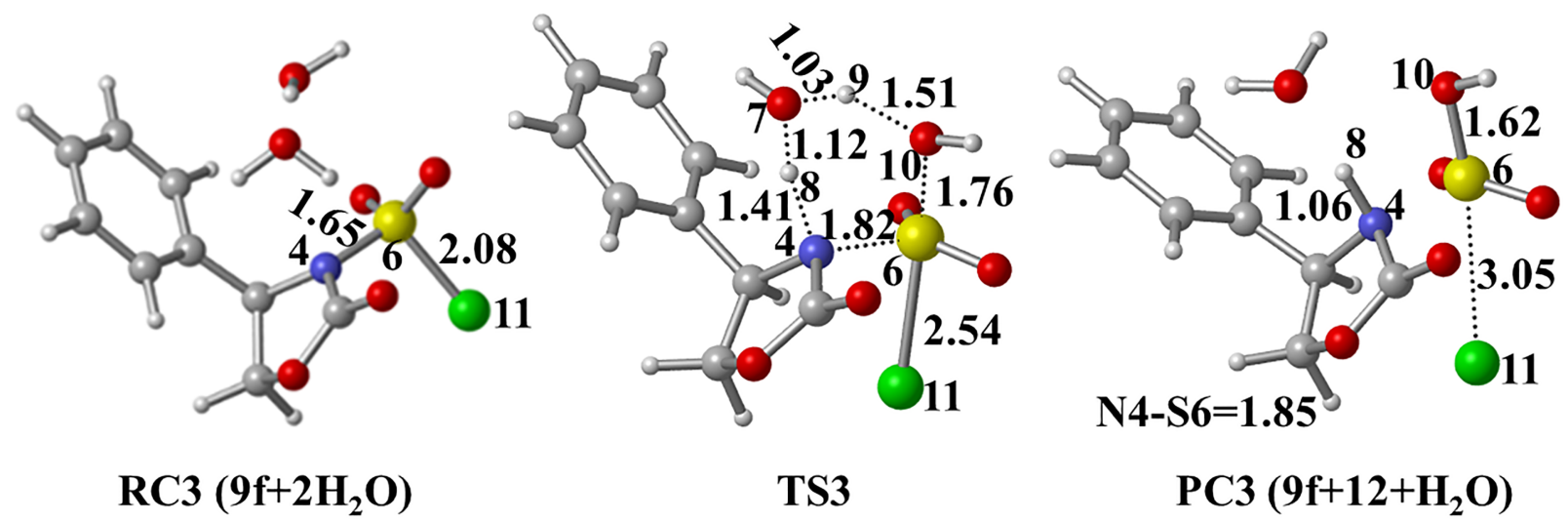

Figure 6: Optimized geometries for the stationary points of path $1 \mathrm{~b}$ at $P C M(D C M) / M 06-2 X / 6-31+G(d, p) / / M 06-2 X / 6-31+G(d, p)$ level. Distances are given in $\AA$. 
mized structures of path 2 are illustrated in Supporting Information File 1, Figure S2.

As can be seen from the potential energy profile (Figure 5), water addition to $\mathbf{1 0}$ is likely to be the rate-determining step for all reaction pathways. Comparison of the calculated Gibbs free energies of activation in DCM reveals that path $1 \mathrm{~b}$ is the most plausible mechanism among the paths studied.

The reaction mechanism for the formation of five-membered cyclic carbonate $\mathbf{8 f}$ has also been investigated theoretically and it is described below (Scheme 4).

A similar transition state has been proposed for the formation of $\mathbf{8 f}$ in the presence of CSI. The mechanism is thought to proceed by ring opening of the epoxide $\mathbf{7 f}$ at the 2-position, followed by nucleophilic attack of $\mathrm{O} 4 \mathrm{on} \mathrm{C} 2$ to afford 16. The formation of $\mathbf{1 6}$ is exergonic by $30.4 \mathrm{kcal} / \mathrm{mol}$ relative to $\mathbf{R C 6}$ $(\mathbf{7 f}+\mathbf{C S I})$ (Figure 7). The optimized geometries are illustrated in Figure 8.

The intermediate $\mathbf{R C 7}\left(\mathbf{1 6}+\mathbf{H}_{\mathbf{2}} \mathrm{O}\right)$, generated by the reaction of CSI with epoxide 7f, reacts with a water molecule to yield $\mathbf{1 7}$. The bond distance C5-N6 is predicted as 1.29, 1.41, and $1.46 \AA$ in structures RC7 $\left(\mathbf{1 6}+\mathbf{H}_{\mathbf{2}} \mathrm{O}\right)$, TS7, and 17, respectively (Figure 9). Besides, the C5-O7 distance is $1.58 \AA$ in TS7; it is shortened to $1.39 \AA$ in $\mathbf{1 7}$. Here, while the $\mathrm{O} 7-\mathrm{H} 8$ single bond is broken, the N6-H8 bond is formed. The corresponding barrier was calculated to be $13.0 \mathrm{kcal} / \mathrm{mol}$ relative to initial reactant complex RC6 (7f+CSI) (Figure 7).

Elimination of 18, accompanied by $\mathrm{C}=\mathrm{O}$ bond formation, constitutes the final step of the reaction observed. Optimized

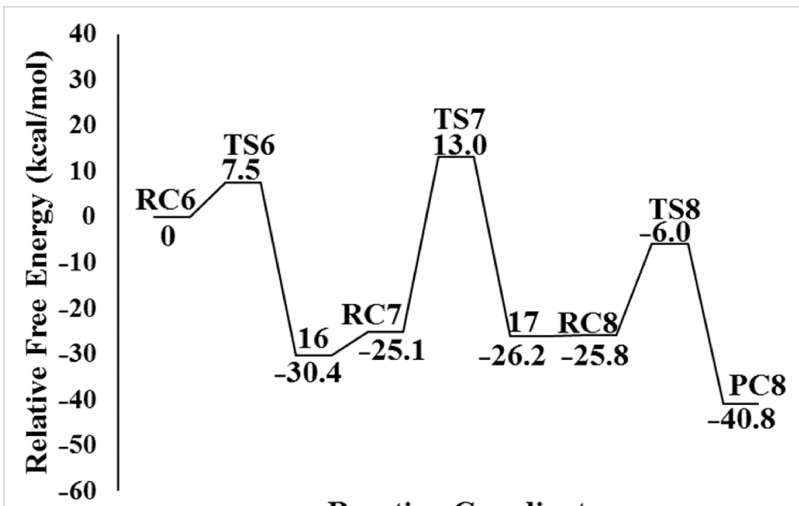

Reaction Coordinate

Figure 7: Potential energy profile and relative Gibbs free energies $(\mathrm{kcal} / \mathrm{mol})$ in DCM related to the formation of $8 \mathrm{f}$ at PCM(DCM)/M06-2X/ $6-31+G(d, p) / / M 06-2 X / 6-31+G(d, p)$ level.

structures are given in Figure 10. The elimination reaction, via the transition state TS8, is facile and leads to the stable product, the five-membered cyclic carbonate $\mathbf{8 f}$ (Figure 7).

In the experimental studies for the reaction of epoxides with CSI, Keshava Murthy and Dhar [41] suggested a stepwise reaction passing through a zwitterionic intermediate (Scheme 2a). De Meijere and co-workers [42] proposed a two-step process involving a 1,5-dipolar intermediate (Scheme 2b). However, in this work, we introduce a new mechanism by providing computational evidence for the asynchronous concerted pathway for the first addition step of epoxides to CSI. Previous computational studies $[37,47]$ involve reactions of CSI with substrates other than epoxides and therefore they are not directly comparable to our reaction; however, they proposed that the reactions of isocyanates may take place through a concerted mechanism. These results are consistent with our computational findings.

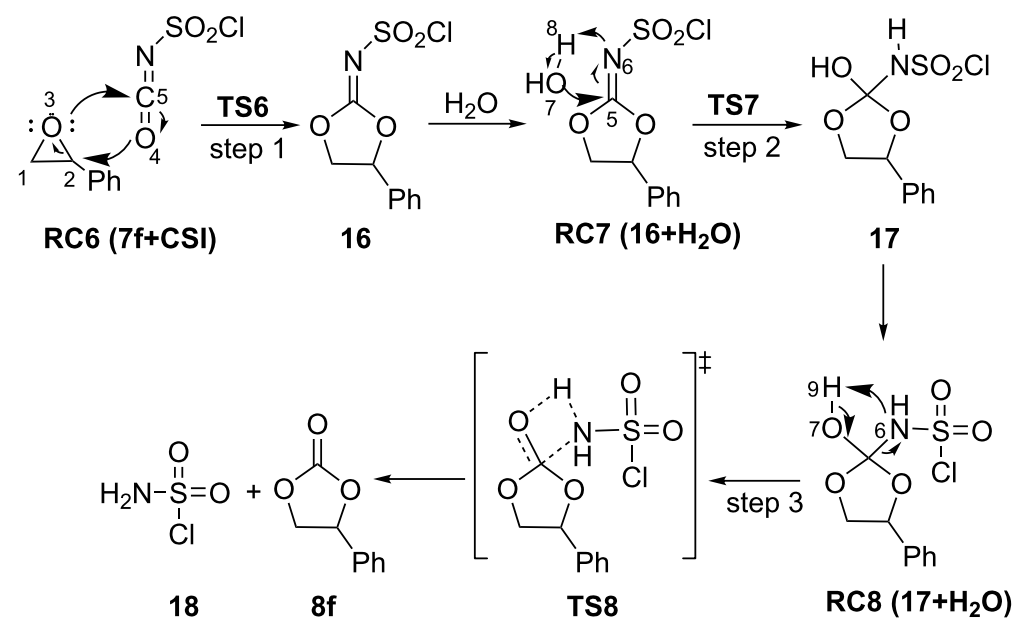




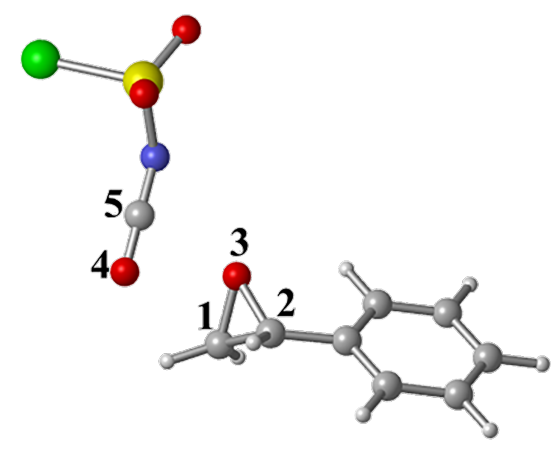

RC6 (7f + CSI)

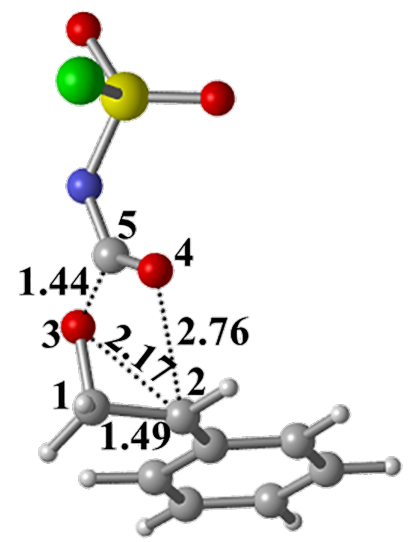

TS6

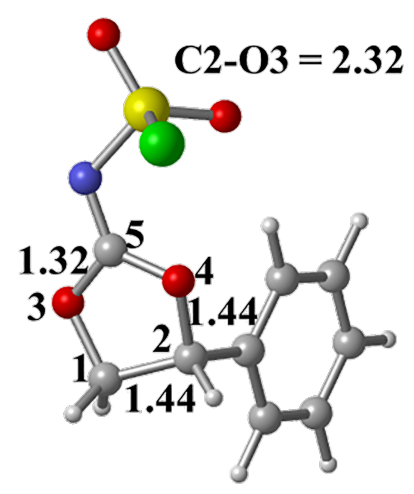

16

Figure 8: Optimized geometries for the stationary points of step 1 for the formation of 16 at $P C M(D C M) / M 06-2 X / 6-31+G(d, p) / / M 06-2 X / 6-31+G(d, p)$ level. Distances are given in $\AA$.

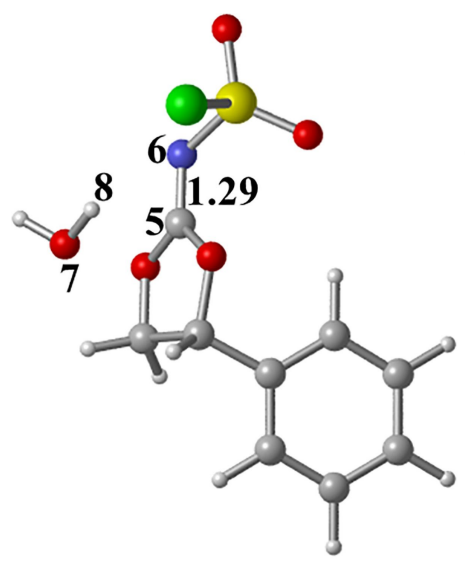

RC7 $\left(16+\mathrm{H}_{2} \mathrm{O}\right)$

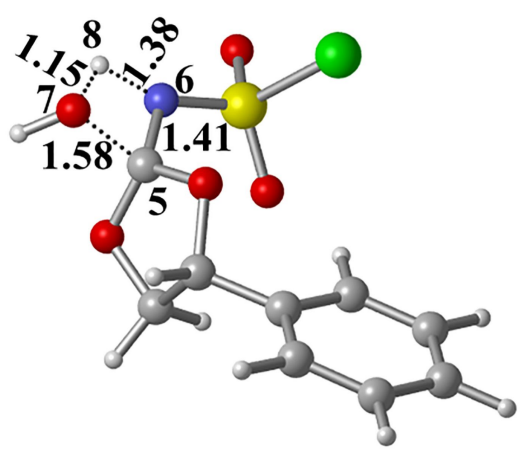

TS7

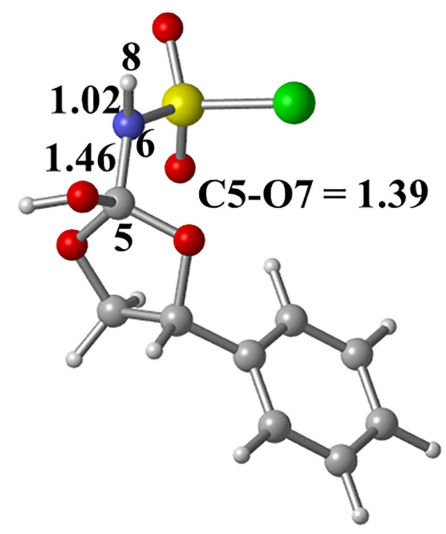

17

Figure 9: Optimized geometries for the stationary points of step 2 for the formation of 17 at $P C M(D C M) / M 06-2 X / 6-31+G(d, p) / / M 06-2 X / 6-31+G(d, p)$ level. Distances are given in $\AA$.

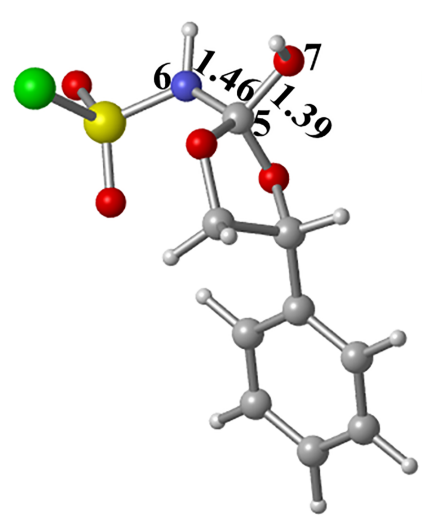

$\operatorname{RC8}\left(17+\mathrm{H}_{2} \mathrm{O}\right)$

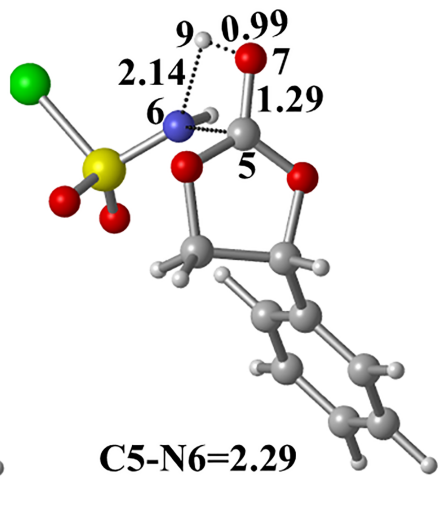

TS8
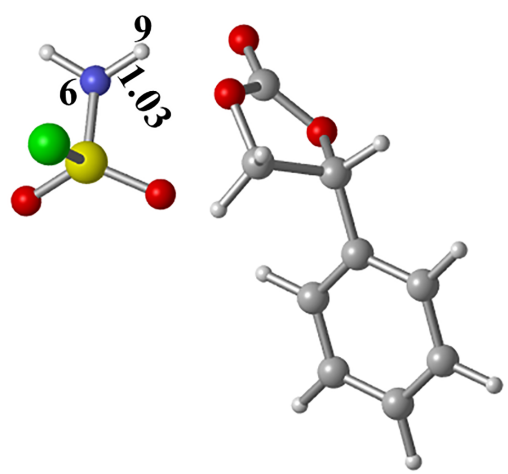

PC8 (8f +18$)$

Figure 10: Optimized geometries for the stationary points of step 3 for the formation of $P C 8$ at $P C M(D C M) / M 06-2 X / 6-31+G(d, p) / / M 06-2 X / 6-31+G(d, p)$ level. Distances are given in $\AA$. 


\section{Conclusion}

In summary, in the first part of the study, we have improved the general synthesis of five-membered cyclic carbonates and oxazolidinones from various epoxides under mild conditions. We also described the synthesis of novel oxazolidinone derivatives $8 \mathbf{i}$ and $8 \mathbf{j}$ and 1,3-dioxolan-2-ones $9 \mathbf{c}$ and $9 \mathbf{i}$. Moreover, an effective and simplistic procedure for the synthesis of known compounds $8 \mathbf{a}-\mathbf{h}, \mathbf{9 a}, \mathbf{b}, \mathbf{9 d - h}$ and $\mathbf{9 j}$ has been reported. Compared to the existing methods in the literature, this versatile conversion has enabled us to create a wide range of cyclic carbonates and oxazolidinones in ratios close to 1:1 using a safe, inexpensive, metal-free reagent, a simple purification method and shorter reaction times via a one-pot reaction. The study presents a useful method for one-pot conversion of epoxides to protected 1,2-diols and 2-amino alcohols in one reaction.

In the computational part of the study, the mechanisms leading to oxazolidinone $9 f$ and cyclic carbonate $8 f$ were examined. The calculated energy difference between the TS1 (leading to 9f) and TS6 (leading to $\mathbf{8 f})$ is very small $(0.5 \mathrm{kcal} / \mathrm{mol})$ but slightly in favor of carbonate $\mathbf{8 f}$ which is in very good agreement with the experimental observation that isolated yields are $49 \%$ for $\mathbf{8 f}$ and $42 \%$ for 9 . The potential energy profiles of the formation of $8 \mathbf{f}$ and $9 f$ are quite similar. IRC calculations revealed that the first step of the mechanisms for the formation of $\mathbf{8 f}$ and $\mathbf{9 f}$ occur asynchronously although in a concerted fashion. The water addition steps are likely to be rate-determining for both reaction mechanisms. Besides, explicit inclusion of water molecules is crucial for lowering the energy barrier making the process plausible without changing the nature of the rate determining step of the formation of $\mathbf{9 f}$.

Our computational results adequately explain the relative yields and confirm the product ratio detected in the experiment as well as the regioselectivity in oxazolidinones The proposed mechanisms in this study confirm the product ratio detected in the experiment. The computational findings provided insight into the formation of experimentally observed oxazolidinone 9 f since its precursor intermediate $\mathbf{1 0}$ has a remarkably lower activation barrier compared to $\mathbf{1 1}$.

\section{Methodology}

All calculations have been carried with the Gaussian 09 program package [58]. Geometry optimizations of all the minima and transition states involved have been performed using M06-2X $[59,60] / 6-31+G(d, p)$ level of theory. The M06-2X functional is known to show good performance in predicting the activation energies and transition state geometries of various reactions [59-61]. Harmonic vibrational frequencies have been calculated at the same level of theory for all stationary points to verify whether they are minima (no imaginary frequencies) or transition states (a single imaginary frequency). Thermodynamic calculations have been performed at $25{ }^{\circ} \mathrm{C}$ and $1 \mathrm{~atm}$. The same level of intrinsic reaction coordinate (IRC) $[62,63]$ calculations have been performed to check the energy profiles connecting each transition state to the two associated minima. The effect of the solvent environment on the reaction pathways has been taken into account by single-point energy calculations on the gas-phase stationary points using a polarizable continuum model (PCM) [64] at M06-2X/6$31+G(d, p)$ level. Structural representations were generated using CYLView [65].

\section{Experimental General considerations}

The epoxides were synthesized from related alkenes with $m$-CPBA and purified in a filter column. All solvents and reagents were used as purchased from commercial suppliers without any purification. Melting points were determined on a melting-point apparatus (Gallenkamp; WA11373) and are uncorrected. IR spectra were obtained from solutions in $0.1 \mathrm{~mm}$ cells and in $\mathrm{CH}_{2} \mathrm{Cl}_{2}$ with a Perkin-Elmer spectrophotometer. ${ }^{1} \mathrm{H}$ and ${ }^{13} \mathrm{C}$ NMR spectra were recorded on Varian and Bruker spectrometers at 400 and $100 \mathrm{MHz}$, respectively, and NMR shifts are presented as $\delta$ in ppm. Elemental analyses were performed on a LECO CHNS-932 apparatus. MS spectra were carried out on an LC-MS high-resolution time of flight (TOF) Agilent 1200/6530 instrument. All column chromatography was performed on silica gel (60-mesh, Merck).

\section{General procedure for the synthesis of five- membered cyclic carbonates and oxazolidinones}

Epoxide 7a (500 mg, $4.54 \mathrm{mmol}, 1$ equiv) was dissolved in $20 \mathrm{~mL}$ dichloromethane. The reaction mixture was cooled to $0{ }^{\circ} \mathrm{C}$, and chlorosulfonyl isocyanate (CSI, $707 \mathrm{mg}, 4.99 \mathrm{mmol}$, 1.1 equiv) was added. The resulting solution was stirred at room temperature for $1 \mathrm{~h}$. Then, water was added to the reaction mixture $(2 \mathrm{~mL})$, and the mixture was stirred for $0.5 \mathrm{~h}$. The reaction mixture was extracted with dichloromethane $(3 \times 20 \mathrm{~mL})$. The organic phase was dried over sodium sulfate and concentrated. Purification was performed through column chromatography on silica gel eluting with hexane/EtOAc (4:1). In all reactions, 1,3dioxolan-2-ones $(\mathbf{8} \mathbf{a}-\mathbf{j})$ were isolated as the first fraction and oxazolidinones, $(\mathbf{9 a}-\mathbf{j})$ as the second fraction.

Octahydrocycloocta $[d]$ oxazol-2(3H)-one (9c): Colourless solid, $R_{\mathrm{f}}=0.4$ (EtOAc/hexanes, 1:5); mp 91-93 ${ }^{\circ} \mathrm{C} ;(268 \mathrm{mg}$, yield $40 \%$ ); ${ }^{1} \mathrm{H}$ NMR (400 MHz, $\left.\mathrm{CDCl}_{3}, \mathrm{ppm}\right) \delta 4.70-4.65(\mathrm{~m}$, $1 \mathrm{H}, \mathrm{CH}-\mathrm{O}), 4.57-4.53(\mathrm{~m}, 1 \mathrm{H}, \mathrm{CH}-\mathrm{N}), 2.28-0.95(\mathrm{~m}, 12 \mathrm{H}$, $\left.6 \times \mathrm{CH}_{2}\right) ;{ }^{13} \mathrm{C} \mathrm{NMR}\left(100 \mathrm{MHz}, \mathrm{CDCl}_{3}, \mathrm{ppm}\right) \delta 148.9(\mathrm{C}=\mathrm{O})$, 
$80.7(\mathrm{C}-\mathrm{O}), 65.7(\mathrm{C}-\mathrm{N}), 26.9\left(\mathrm{CH}_{2}\right), 25.3\left(\mathrm{CH}_{2}\right), 28.4\left(\mathrm{CH}_{2}\right)$, $25.3\left(\mathrm{CH}_{2}\right), 24.9\left(\mathrm{CH}_{2}\right), 24.2\left(\mathrm{CH}_{2}\right)$; IR $\left(\mathrm{CHCl}_{3}, \mathrm{~cm}^{-1}\right)$ : 3251, 2928, 2863, 1805, 1410, 1358, 1210, 1175, 1034; anal. calcd for: $\mathrm{C}, 63.88 ; \mathrm{H}, 8.93 ; \mathrm{N}, 8.28$; found: 63.56; $\mathrm{H}, 9.04 ; \mathrm{N}, 8.54$; HRMS-ESI $(\mathrm{m} / \mathrm{z}):[\mathrm{M}+\mathrm{H}]^{+}$calcd for $\mathrm{C}_{9} \mathrm{H}_{15} \mathrm{NO}_{2}{ }^{+}, 169,1097$; found, 169,1086 .

3a,4,9,9a-Tetrahydro-4,9-methanonaphtho[ $2,3-$ d][1,3]dioxol-2-one (8i): Colourless solid, $R_{\mathrm{f}}=0.5(\mathrm{EtOAc} /$ hexanes, 1:5); mp 102-104 ${ }^{\circ} \mathrm{C}$. (287 mg, yield 43\%); ${ }^{1} \mathrm{H}$ NMR (400 MHz, $\left.\mathrm{CDCl}_{3}, \mathrm{ppm}\right) \delta$ 7.27-7.18 (m, 4H, ArH), $4.62(\mathrm{~s}$, $2 \mathrm{H}, \mathrm{CH}-\mathrm{O}), 3.62(\mathrm{~s}, 2 \mathrm{H}, \mathrm{CH}), 2.16\left(\mathrm{~s}, 2 \mathrm{H}, \mathrm{CH}_{2}\right) ;{ }^{13} \mathrm{C} \mathrm{NMR}$ $\left(100 \mathrm{MHz}, \mathrm{CDCl}_{3}, \mathrm{ppm}\right) \delta 154.0(\mathrm{C}=\mathrm{O}), 142.2(\mathrm{Ar}), 128.1(\mathrm{Ar})$, 123.3 (Ar), $80.5(\mathrm{C}-\mathrm{O}), 47.9(\mathrm{CH}), 41.6\left(\mathrm{CH}_{2}\right)$; IR $\left(\mathrm{CHCl}_{3}\right.$, $\left.\mathrm{cm}^{-1}\right)$ : 2932, 1804, 1460, 1160, 1066, 976; anal. calcd for: C, 71.28; H, 4.98; found: C, 71.43; H, 4.73; HRMS-ESI $(\mathrm{m} / \mathrm{z})$ : $[\mathrm{M}+\mathrm{H}]^{+}$calcd for $\mathrm{C}_{12} \mathrm{H}_{10} \mathrm{O}_{3}{ }^{+}, 202,0624$; found, 202,0637.

3a,4,9,9a-Tetrahydro-4,9-methanonaphtho[2,3-d]oxazol2(3H)-one (9i): Colourless solid, $R_{\mathrm{f}}=0.3($ EtOAc/hexanes, 1:5); mp 133-135 ${ }^{\circ} \mathrm{C}$. (235 mg, yield $\left.37 \%\right) ;{ }^{1} \mathrm{H}$ NMR (400 MHz, $\left.\mathrm{CDCl}_{3}, \mathrm{ppm}\right) \delta 7.30-7.20(\mathrm{~m}, 4 \mathrm{H}, \mathrm{ArH}) .4 .94$ (s, $1 \mathrm{H}, \mathrm{CH}-\mathrm{O}), 3.95(\mathrm{~s}, 1 \mathrm{H}, \mathrm{CH}-\mathrm{N}), 2.27-2.24(\mathrm{~m}, 2 \mathrm{H}, \mathrm{CH})$, 2.17-2.11 (m, 2H, $\left.\mathrm{CH}_{2}\right) ;{ }^{13} \mathrm{C} \mathrm{NMR}\left(100 \mathrm{MHz}, \mathrm{CDCl}_{3}, \mathrm{ppm}\right) \delta$ $162.7(\mathrm{C}=\mathrm{O}), 141.4$ (Ar), 128.5 (Ar), 123.6 (Ar), 85.1 (Ar), 57.8 (C-O), $47.9(\mathrm{C}-\mathrm{N}), 41.9(\mathrm{CH}), 29.9\left(\mathrm{CH}_{2}\right)$; IR $\left(\mathrm{CHCl}_{3}, \mathrm{~cm}^{-1}\right)$ : 3340, 2918, 1802, 1647, 1461, 1368, 1166, 1001; anal. calcd for: $\mathrm{C}, 71.63 ; \mathrm{H}, 5.51 ; \mathrm{N}, 6.96$; found: $\mathrm{C}, 71.48 ; \mathrm{H}, 5.72 ; \mathrm{N}$, 6.79; HRMS-ESI $(m / z):[\mathrm{M}+\mathrm{H}]^{+}$calcd for $\mathrm{C}_{12} \mathrm{H}_{11} \mathrm{NO}_{2}{ }^{+}$, 201,0784; found, 201,0796.

3a-Phenylhexahydrobenzo $[d][1,3]$ dioxol-2-one $(8 \mathbf{j})$ : Colourless solid, $R_{\mathrm{f}}=0.4\left(\right.$ EtOAc/hexanes, 1:5); mp 97-99 ${ }^{\circ} \mathrm{C}$; (275 mg, yield 44\%); ${ }^{1} \mathrm{H}$ NMR (400 $\left.\mathrm{MHz}, \mathrm{CDCl}_{3}, \mathrm{ppm}\right) \delta$ $7.42-7.27(\mathrm{~m}, 5 \mathrm{H}, \mathrm{ArH}), 4.81(\mathrm{t}, J=4.4 \mathrm{~Hz}, 1 \mathrm{H}, \mathrm{CH}-\mathrm{O})$,

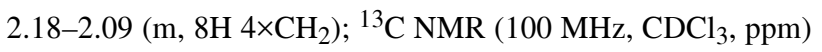
ठ 154.7 (C=O), 140.9 (Ar), 129.1 (Ar), 128.8 (Ar), 124.9 (Ar), 85.2 (C-O), $81.2(\mathrm{C}-\mathrm{O}), 34.9\left(\mathrm{CH}_{2}\right), 26.7\left(\mathrm{CH}_{2}\right), 19.7\left(\mathrm{CH}_{2}\right)$, $18.2\left(\mathrm{CH}_{2}\right)$; IR $\left(\mathrm{CHCl}_{3}, \mathrm{~cm}^{-1}\right): 2935,2865,1803,1449,1205$, 1028; anal. calcd for: $\mathrm{C}, 71.54$; $\mathrm{H}, 6.47$; found: $\mathrm{C}, 71.65$; $\mathrm{H}$, 6.38; HRMS-ESI $(\mathrm{m} / \mathrm{z}):[\mathrm{M}+\mathrm{H}]^{+}$calcd for $\mathrm{C}_{13} \mathrm{H}_{14} \mathrm{O}_{3}{ }^{+}$, 218,0937; found, 218,0946 .

\section{Supporting Information}

\section{Supporting Information File 1}

Experimental, analytical and calculated data. [https://www.beilstein-journals.org/bjoc/content/ supplementary/1860-5397-16-148-S1.pdf]

\section{Funding}

We are grateful to the Scientific Research Project of the Atatürk University of Turkey (BAP) for a grant [2016/158].

\section{ORCID ${ }^{\circledR}$ iDs}

Ufuk Atmaca - https://orcid.org/0000-0002-5598-0443 Murat Çelik - https://orcid.org/0000-0003-3485-7822

\section{Preprint}

A non-peer-reviewed version of this article has been previously published as a preprint doi:10.3762/bxiv.2020.49.v1

\section{References}

1. Stevens, D. L.; Dotter, B.; Madaras-Kelly, K. Expert Rev. Anti-Infect. Ther. 2004, 2, 51-59. doi:10.1586/14787210.2.1.51

2. Wang, J.; Xia, L.; Wang, R.; Cai, Y. Front. Pharmacol. 2019, 10, 1389. doi:10.3389/fphar.2019.01389

3. Barbachyn, M. R.; Ford, C. W. Angew. Chem., Int. Ed. 2003, 42, 2010-2023. doi:10.1002/anie.200200528

4. Orac, C. M.; Zhou, S.; Means, J. A.; Boehm, D.; Bergmeier, S. C.; Hines, J. V. J. Med. Chem. 2011, 54, 6786-6795. doi:10.1021/jm2006904

5. Ager, D. J.; Prakash, I.; Schaad, D. R. Chem. Rev. 1996, 96, 835-876. doi:10.1021/cr9500038

6. Flynn, B. L.; Manchala, N.; Krenske, E. H. J. Am. Chem. Soc. 2013, 135, 9156-9163. doi:10.1021/ja4036434

7. Wan, N.; Zhou, X.; Ma, R.; Tian, J.; Wang, H.; Cui, B.; Han, W.; Chen, Y. Adv. Synth. Catal. 2020, 362, 1201-1207. doi:10.1002/adsc.201901412

8. Narina, S. V.; Kumar, T. S.; George, S.; Sudalai, A. Tetrahedron Lett. 2007, 48, 65-68. doi:10.1016/j.tetlet.2006.11.016

9. Asano, M.; Nagasawa, C.; Suzuki, M.; Nishiyama, S.; Sugai, T. Biosci., Biotechnol., Biochem. 2005, 69, 145-148. doi:10.1271/bbb.69.145

10. Xin, Q.; Fan, H.; Guo, B.; He, H.; Gao, S.; Wang, H.; Huang, Y.; Yang, Y. J. Med. Chem. 2011, 54, 7493-7502. doi:10.1021/jm200614t

11. Zhanel, G. G.; Love, R.; Adam, H.; Golden, A.; Zelenitsky, S.; Schweizer, F.; Gorityala, B.; Lagacé-Wiens, P. R. S.; Rubinstein, E.; Walkty, A.; Gin, A. S.; Gilmour, M.; Hoban, D. J.; Lynch, J. P., 3rd.; Karlowsky, J. A. Drugs 2015, 75, 253-270. doi:10.1007/s40265-015-0352-7

12. Mai, A.; Artico, M.; Esposito, M.; Ragno, R.; Sbardella, G.; Massa, S. Farmaco 2003, 58, 231-241. doi:10.1016/s0014-827x(03)00016-8

13. Youdim, M. B. H.; Edmondson, D.; Tipton, K. F. Nat. Rev. Neurosci. 2006, 7, 295-309. doi:10.1038/nrn1883

14. Gunal, S. E.; Tuncel, S. T.; Kelekci, N. G.; Ucar, G.; Dursun, B. Y.; Erdem, S. S.; Dogan, I. Bioorg. Chem. 2018, 77, 608-618. doi:10.1016/j.bioorg.2018.02.003

15. Buckler, J. N.; Meek, T.; Banwell, M. G.; Carr, P. D. J. Nat. Prod. 2017, 80, 2088-2093. doi:10.1021/acs.jnatprod.7b00303

16. Peña-López, M.; Neumann, H.; Beller, M. Eur. J. Org. Chem. 2016, 3721-3727. doi:10.1002/ejoc.201600476

17. Comerford, J. W.; Ingram, I. D. V.; North, M.; Wu, X. Green Chem. 2015, 17, 1966-1987. doi:10.1039/c4gc01719f

18. Aravindan, V.; Gnanaraj, J.; Madhavi, S.; Liu, H.-K. Chem. - Eur. J. 2011, 17, 14326-14346. doi:10.1002/chem.201101486 
19. Tezuka, K.; Koda, K.; Katagiri, H.; Haba, O. Polym. Bull. 2015, 72, 615-626. doi:10.1007/s00289-014-1295-y

20. Azechi, M.; Matsumoto, K.; Endo, T. J. Polym. Sci., Part A: Polym. Chem. 2013, 51, 1651-1655. doi:10.1002/pola.26538

21. Brandão, P.; Pineiro, M.; Pinho e Melo, T. M. V. D. Eur. J. Org. Chem. 2019, 7188-7217. doi:10.1002/ejoc.201901335

22. Matsunaga, S.; Kumagai, N.; Harada, S.; Shibasaki, M. J. Am. Chem. Soc. 2003, 125, 4712-4713. doi:10.1021/ja034787f

23. Tominaga, K.-i.; Sasaki, Y. Synlett 2002, 307-309. doi:10.1055/s-2002-19780

24. Morales-Nava, R.; Fernández-Zertuche, M.; Ordóñez, M. Molecules 2011, 16, 8803-8814. doi:10.3390/molecules16108803

25. Pulla, S.; Unnikrishnan, V.; Ramidi, P.; Sullivan, S. Z.; Ghosh, A.; Dallas, J. L.; Munshi, P. J. Mol. Catal. A: Chem. 2011, 338, 33-43. doi:10.1016/j.molcata.2011.01.022

26. Liu, J.-M.; Peng, X.-G.; Liu, J.-H.; Zheng, S.-Z.; Sun, W.; Xia, C.-G. Tetrahedron Lett. 2007, 48, 929-932. doi:10.1016/j.tetlet.2006.12.028

27. Gabriele, B.; Salerno, G.; Brindisi, D.; Costa, M.; Chiusoli, G. P. Org. Lett. 2000, 2, 625-627. doi:10.1021/ol9913789

28. Zhou, M.; Zheng, X.; Wang, Y.; Yuan, D.; Yao, Y. ChemCatChem 2019, 11, 5783-5787. doi:10.1002/cctc.201900221

29. Feroci, M.; Orsini, M.; Sotgiu, G.; Rossi, L.; Inesi, A. J. Org. Chem. 2005, 70, 7795-7798. doi:10.1021/jo0511804

30. Miller, A. W.; Nguyen, S. T. Org. Lett. 2004, 6, 2301-2304. doi:10.1021/ol049689t

31. Speranza, G. P.; Peppel, W. J. J. Org. Chem. 1958, 23, 1922-1924. doi:10.1021/j001106a027

32. Baronsky, T.; Beattie, C.; Harrington, R. W.; Irfan, R.; North, M.; Osende, J. G.; Young, C. ACS Catal. 2013, 3, 790-797. doi:10.1021/cs4001046

33. North, M.; Pasquale, R.; Young, C. Green Chem. 2010, 12, 1514-1539. doi:10.1039/c0gc00065e

34. Aoyagi, N.; Furusho, Y.; Endo, T. Synthesis 2020, 52, 150-158. doi:10.1055/s-0037-1610735

35. Martín, C.; Fiorani, G.; Kleij, A. W. ACS Catal. 2015, 5, 1353-1370. doi:10.1021/cs5018997

36. Shimojo, M.; Matsumoto, K.; Hatanaka, M. Tetrahedron 2000, 56, 9281-9288. doi:10.1016/s0040-4020(00)00904-2

37. Shellhamer, D. F.; Davenport, K. J.; Hassler, D. M.; Hickle, K. R.; Thorpe, J. J.; Vandenbroek, D. J.; Heasley, V. L.; Boatz, J. A.; Reingold, A. L.; Moore, C. E. J. Org. Chem. 2010, 75, 7913-7916. doi:10.1021/jo101240s

38. Shellhamer, D. F.; Alexander, K. L.; Bunting, S. A.; Elwin, S. L.; Licata, C. J.; Milligan, J. C.; Robinson, R. D.; Shipowick, D. E.; Smith, L. B.; Perry, M. C. Synthesis 2015, 47, 1944-1950. doi:10.1055/s-0034-1380553

39. Dhar, D. N.; Murthy, K. S. K. Synthesis 1986, 437-449. doi:10.1055/s-1986-31671

40. Keshava Murthy, K. S.; Dhar, D. N. Synth. Commun. 1984, 14, 687-695. doi:10.1080/00397918408063755

41. Murthy, K. S. K.; Dhar, D. N. J. Heterocycl. Chem. 1984, 21 , 1721-1725. doi:10.1002/jhet.5570210630

42. Lorincz, T.; Erden, I.; Näder, R.; de Meijere, A. Synth. Commun. 1986, 16, 123-130. doi:10.1080/00397918608057699

43. Atmaca, U.; Yıldırım, A.; Taslimi, P.; Çelik, S. T.; Gülçin, İ.; Supuran, C. T.; Çelik, M. J. Biochem. Mol. Toxicol. 2018, 32, e22173. doi:10.1002/jbt.22173
44. Daryadel, S.; Atmaca, U.; Taslimi, P.; Gülçin, I.; Çelik, M. Arch. Pharm. (Weinheim, Ger.) 2018, 351, 1800209. doi:10.1002/ardp.201800209

45. Atmaca, U.; Daryadel, S.; Taslimi, P.; Çelik, M.; Gülçin, İ. Arch. Pharm. (Weinheim, Ger.) 2019, 352, e1900200. doi:10.1002/ardp.201900200

46. Atmaca, U. Tetrahedron 2019, 75, 130467. doi:10.1016/j.tet.2019.130467

47. Darù, A.; Roca-López, D.; Tejero, T.; Merino, P. J. Org. Chem. 2016, 81, 673-680. doi:10.1021/acs.joc.5b02645

48. Laserna, V.; Fiorani, G.; Whiteoak, C. J.; Martin, E.; Escudero-Adán, E.; Kleij, A. W. Angew. Chem., Int. Ed. 2014, 53, 10416-10419. doi:10.1002/anie.201406645

49. Scholz, K.-H.; Heine, H.-G.; Hartmann, W. Justus Liebigs Ann. Chem. 1977, 2027-2035. doi:10.1002/jlac.197719771123

50. Steinbauer, J.; Spannenberg, A.; Werner, T. Green Chem. 2017, 19, 3769-3779. doi:10.1039/c7gc01114h

51. Hu, N. X.; Aso, Y.; Otsubo, T.; Ogura, F. J. Org. Chem. 1989, 54, 4398-4404. doi:10.1021/jo00279a031

52. Yang, X.; Bumbu, V. D.; Liu, P.; Li, X.; Jiang, H.; Uffman, E. W.; Guo, L.; Zhang, W.; Jiang, X.; Houk, K. N.; Birman, V. B. J. Am. Chem. Soc. 2012, 134, 17605-17612. doi:10.1021/ja306766n

53. Sukhanova, A. A.; Puchkin, I. A.; Vasil'ev, A. A.; Zlotin, S. G. Tetrahedron: Asymmetry 2017, 28, 1834-1841. doi:10.1016/j.tetasy.2017.10.024

54. Miceli, C.; Rintjema, J.; Martin, E.; Escudero-Adán, E. C.; Zonta, C.; Licini, G.; Kleij, A. W. ACS Catal. 2017, 7, 2367-2373. doi:10.1021/acscatal.7b00109

55. Lebel, H.; Mamani Laparra, L.; Khalifa, M.; Trudel, C.; Audubert, C.; Szponarski, M.; Dicaire Leduc, C.; Azek, E.; Ernzerhof, M. Org. Biomol. Chem. 2017, 15, 4144-4158. doi:10.1039/c7ob00378a

56. Tanaka, S.; Gunasekar, R.; Tanaka, T.; Iyoda, Y.; Suzuki, Y.; Kitamura, M. J. Org. Chem. 2017, 82, 9160-9170. doi:10.1021/acs.joc.7b01181

57. Tantillo, D. J. J. Phys. Org. Chem. 2008, 21, 561-570. doi:10.1002/poc. 1320

58. Gaussian 09, Revision B.01; Gaussian, Inc.: Wallingford, CT, 2009.

59. Zhao, Y.; Truhlar, D. G. Theor. Chem. Acc. 2008, 120, 215-241. doi:10.1007/s00214-007-0310-x

60. Zhao, Y.; Truhlar, D. G. Acc. Chem. Res. 2008, 41, 157-167. doi:10.1021/ar700111a

61. Guleli, M.; Erdem, S. S.; Ocal, N.; Erden, I.; Sari, O. Res. Chem. Intermed. 2019, 45, 2119-2134. doi:10.1007/s11164-018-03721-z

62. Gonzalez, C.; Schlegel, H. B. J. Chem. Phys. 1989, 90, 2154-2161. doi:10.1063/1.456010

63. Gonzalez, C.; Schlegel, H. B. J. Phys. Chem. 1990, 94, 5523-5527. doi:10.1021/j100377a021

64. Miertuš, S.; Scrocco, E.; Tomasi, J. Chem. Phys. 1981, 55, 117-129. doi:10.1016/0301-0104(81)85090-2

65. CYLview, version 1.0b; Université de Sherbrooke: Sherbrooke, Québec, Canada, 2009, http://www.cylview.org 


\section{License and Terms}

This is an Open Access article under the terms of the Creative Commons Attribution License (http://creativecommons.org/licenses/by/4.0). Please note that the reuse, redistribution and reproduction in particular requires that the authors and source are credited.

The license is subject to the Beilstein Journal of Organic Chemistry terms and conditions:

(https://www.beilstein-journals.org/bjoc)

The definitive version of this article is the electronic one which can be found at:

$\underline{\text { doi:10.3762/bjoc. } 16.148}$ 